\title{
The Impact of Corporate Social Responsibility on Firms' Financial Performance in South Africa
}

\author{
Sukanya Chetty', Rebekah Naidoo', Yudhvir Seetharam ${ }^{1}$
}

\begin{abstract}
If Corporate Social Responsibility (CSR) activities are beyond a firm's legal obligations and potentially require a sacrifice in short-term profits, why do firms promote CSR? This question motivates this investigation of the impact of CSR on a firm's Corporate Financial Performance (CFP). This relationship is examined for the period from 2004 to 2013 in South Africa. We assess the short-term impact of CSR announcements on financial returns of firms included in or excluded from the Johannesburg Securities Exchange Socially Responsible Investment Index and determine whether there is a difference in the long-term CFP between these two groups for the entire period. The event study methodology shows that investors were rewarded in 2004 and 2012, when firms entered the index, and were penalized in 2013, when firms exited the index. When using regression analysis, the various industries provide mixed results between CSR and CFP for firms over the long term. Based on these results, we find that CSR activities lead to no significant differences in financial performance.
\end{abstract}

KEY WORDS: $\quad$ Corporate Social Responsibility, financial markets, South Africa

JEL Classification: $\quad$ G15, G30

${ }^{1}$ University of the Witwatersrand - School of Economic and Business Sciences, South Africa

\section{Introduction}

Corporate Social Responsibility (CSR) can be defined as the treatment of all stakeholders in a responsible and ethical manner (Hopkins, 2003). CSR activities are voluntary actions that go beyond a firm's interests and legal requirements to promote a social good (McWilliams \& Siegel, 2001). This gives rise to the following $\square$ important questions:

Correspondence concerning this article should be addressed to: Yudhvir Seetharam, University of the Witwatersrand - School of Economic and Business Sciences, 1 Yale Road Braamfontein, Johannesburg, Gauteng 2001, South Africa, T: +27117178117. E-mail:yudhvir.seetharam@wits.ac.za
If CSR activities are beyond a firm's legal obligations and potentially require a sacrifice in shortterm profits, why do firms promote CSR? Is the sacrifice of short-term profits compensated by improvement in firms' long-term financial performance? (Choi, Kwak, \& Choe, 2010, p. 292)

While there has been a growing body of global research pertaining to the effect of CSR on Corporate Financial Performance (CFP) since the 1960s, no real consensus has been reached regarding the relationship between CSR and CFP. Wilson (2007) states that developing economies are unable to withstand the high standards of CSR used in its developed counterparts. Heese (2005) and Jamali and Mirshak (2007) support 
this statement, purporting that sustainability practices are not fully evolved in African economies. Due to the inability of emerging African economies to relate to the CSR standards of the rest of the world, few studies have been conducted on the sustainable practices of African firms. However, Baskin (2006) found that South Africa has not only a significant Socially Responsible Investment (SRI) Index among emerging economies but also the most developed CSR outlook in Africa and the Middle East as a result of the domestic pressures of CSR and the influence of corporate governance (Baskin, 2006).

Studies have been conducted with the aim of explaining the relationship between CSR and financial performance in both developed economies such as the United States (US) and Britain and developing economies such as Brazil, Nigeria, Taiwan, Turkey and Indonesia. However, there exists a gap in the literature pertaining to South Africa. The topic of CSR and CFP has been well documented for developed economies (Balabanis, Phillips \& Lyall, 1998; Tsoutsoura, 2004) as well as emerging economies (Aras, Aybars \& Kutlu, 2009; Crisóstomo, Freire \& de Vasconcellos, 2011). However, little research has been conducted in an African context. This study aims to identify whether there is a relationship between CSR and CFP in a South African context. There are two main objectives of this study:

Objective One is to determine the short-term impact of CSR announcements on the financial returns of firms included in or excluded from the Johannesburg Securities Exchange (JSE) Socially Responsible Investment (SRI) Index. The hypotheses pertaining to this objective can be established according to Curran and Moran (2007), as follows:

$H_{0}{ }^{l}$ : Announcements of firms included in or excluded from the JSE SRI Index will be associated with no significant share price changes for those firms

$H_{1}{ }^{1}$ : Announcements of firms included in the JSE SRI Index will be associated with significant (positive or negative) share price changes for those firms

Objective Two is to determine whether there is a difference in the long-term financial performance of constituent firms of the JSE SRI Index for the entire period and those that are listed on the JSE All Share Index (ALSI) but are not JSE SRI Index constituents for the entire period. The hypotheses pertaining to this objective can be set up as follows:
$H_{0}^{2}$ : There is no significant difference in financial performance between constituents and non-constituents of the JSE SRI Index.

$\mathrm{H}_{1}^{2}$ : There is a significant difference in financial performance between constituents and non-constituents of the JSE SRI Index.

Freeman (1984) suggests that corporate decisions involve a trade-off between shareholder value and other stakeholder benefits. Therefore, some scholars believe CSR initiatives deplete shareholder value due to the decrease in profits. Others, such as Bagnoli and Watts (2003), believe CSR initiatives increase financial performance. The mixed results found by previous researchers in international markets may be puzzling to South African researchers and investors, as no real consensus has been reached regarding CSR and financial performance.

This study on the effect of CSR announcements will help determine the short-term impact on capital market performance of firms' entrance into and exit from the JSE SRI Index - whether firms are penalized, rewarded or remain neutral to such announcements - in terms of market-based indicators. As a result, one can gain insight into the impact of CSR on shareholder value as well as investor preferences (Becchetti et al., 2012). Thereafter, the extension of the study provides a longterm view on the performance of firms on the JSE SRI Index relative to firms that are not on the JSE SRI Index but are on the overall index (JSE ALSI). This provides insight into the effects of CSR initiatives on financial performance in terms of accounting-based indicators (Heal, 2008). The results of the study will be beneficial not only to academics focusing on CSR but also to business leaders, managers and investors who are concerned with the impact of CSR on firms' financial performance.

The remainder of the study is structured as follows: Chapter 2 outlines the relevant literature on this particular topic; Chapter 3 describes the methodology, specifically the data collection and the overall research design; Chapter 4 presents a discussion of the obtained results; Chapter 5 provides concluding remarks.

\section{Literature review}

\subsection{Theoretical background}

Over the years, the growing importance of CSR for firms has arisen from the pressure various stakeholders place on these firms to engage in additional CSR 
investments (McWilliams \& Siegel, 2000). However, managers across various firms do not share the same attitudes towards these concerns about CSR. On one spectrum, there exists managers who believe that in communicating their better social performance with stakeholders such as investors, consumers, suppliers, bankers and employees, the firm's reputation with these stakeholders may improve (Orlitzky, Schmidt \& Rynes, 2003). For example, Spicer (1978) found firms' relationships to improve with bankers and investors if they had a higher level of Corporate Social Performance (CSP), thus allowing these firms to access capital and better contractual terms. Bagnolli and Watts (2003) found that firms with high CSP attracted more socially responsible consumers and experienced improved financial performance. Another reason management may address these concerns is because CSR may serve as a strategy to create and maintain a competitive advantage. By adding value to society, firms realize that they can transcend from doing good to doing better in order to survive and compete in the competitive global market (Lin, Yang \& Liou, 2009).

In contrast, some managers find that such CSR activities deplete their profits in the long term and try to resist such initiatives because of this perceived tradeoff. Managers who feel that satisfying shareholder interests is a priority and that the primary objective of a business is to make money may render ethical considerations unimportant; therefore, such CSR investments may hurt the financial performance of the business (Friedman, 1970). Ullman (1985) asserts that this negative relationship could result from the inefficient use of resources as firms try to meet the demands of different stakeholders such that the costs incurred from socially responsible actions place these firms at an economic disadvantage.

There is an alternative approach to determining the impact of CSR on a firm's CFP, which is by finding if there is any abnormal financial gain among firms listed on the SRI indices. There has been limited research on the capital market reaction to socially responsible and non-socially responsible activities by corporations. Extant research examines the relationship between positive and negative announcements and changes in stock prices or daily returns. Positive announcements reflect firms that are added to the index, whereas negative announcements reflect firms that have been deleted from the index (Curran \& Moran, 2007). Calculating abnormal returns at an announcement date separates the effect of a change in CSR on corporate performance from the reverse causality effect of corporate performance on the CSR of the firm (Becchetti et al., 2012). This is the advantage of investigating the impact of CSR on CFP in financial markets.

From the above, it can be seen that the relationship between CSR and CFP is an important issue for corporate management to consider, and as a result, Preston (1990) suggests that social issues deserve the same attention and rigorous analysis as market factors in determining long-term success.

\subsection{Measures of CSR}

The lack of consensus regarding CSR measurement has been a problem when attempting to determine the impact of CSR on CFP. In some cases, subjective measures such as surveys by faculty members or students (Heinze, 1976; Moskowitz, 1972) or even reputation indices whereby firms are rated and ranked on the basis of various dimensions of social performance (Balabanis et al., 1998; Preston \& O’Bannon, 1997) are used. In other cases, researchers such as Babalola (2012) utilize content analysis, which consists of CSR disclosures as stated in annual reports. In countries in which the above methods are not feasible, CSR indices are more commonly used as a dummy variable in terms of regression analysis, whereby a value of 1 is used when firms are included in the Index and a value of 0 is used when they are not (Crisóstomo et al., 2011; McWilliams \& Siegel, 2000; Tsoutsoura, 2004).

Each of the above measures is subject to limitations. Surveys may be subject to bias, as they are based on the researchers' own subjective views. The credibility of the ratings is highly subjective and depends not only on the accuracy of information available to assessors but also on their expertise (Balabanis et al., 1998). Content analysis may be subjective according to the researchers' choice of variables to measure, and firms may not implement their reported actions.

\subsection{Measures of financial performance}

Similar to CSR measurements, there is a lack of consensus concerning the optimal financial performance measurement instrument to employ. Many researchers utilize accounting measures such as Return on 
Equity (ROE), Return on Assets (ROA), Return on Sales (ROS), Return on Capital Employed (ROCE) and Earnings per Share (EPS) (Cochran \& Wood, 1984; Waddock \& Graves, 1997). Other researchers such as Vance (1975) use market-based measures of financial performance, such as investor returns; others, such as Balabanis et al. (1998) and Choi et al. (2010), employ a combination of both accounting- and market-based measures. Both accounting- and market-based measures represent different perspectives on financial performance and have different implications.

Accounting-based measures are said to only capture the historical aspects of a firm's financial performance (McGuire, Schneeweis \& Hill, 1986). These measures are subject to bias, as they are affected by managerial manipulation as well as by different accounting procedures (Aras et al., 2009). Market-based measures focus on a firm's future performance as opposed to past performance; thus, they are less susceptible to managerial manipulation and different accounting procedures (Aras et al., 2009). To account for these shortfalls, this study utilizes both accounting- and market-based measures.

\subsection{The JSE SRI Index}

The JSE SRI Index serves as an important mechanism for investors to identify good, socially responsible corporations, as well as a benchmark for firms seeking to improve their CSR. The Index was first launched in May 2004 in response to the growing global demand for SRI and was the first CSR Index to be established and owned by an exchange in an emerging economy (Heese, 2005). The main focus of this index is to promote sustainable business practices. Before the inception of the index, South African firms were already actively involved in CSR activity; the origins of SRI in South Africa can be traced back to the early 1990s, when trade unions refused to invest members' contributions in firms that supported the apartheid regime (De Cleene \& Sonnenberg, 2004). A more balanced and broader approach was needed to encompass the triple bottom line, which comprises Economic, Social and Governance (ESG) considerations (JSE [Johannesburg Stock Exchange], 2010), resulting in the formation of the JSE SRI Index.

In order for a firm to be considered for the JSE SRI Index, the JSE SRI Index Advisory Committee annu- ally assesses firms based on an array of criteria. The criteria requires firms to be constituents of the FTSE/ JSE All Share Index, and they also need to comply with the ESG standards through a number of different indicators that measure corporate policy, practice and reporting (JSE, 2010).

The criteria of the JSE SRI Index is constantly evolving, ensuring that South African sustainability practices are aligned to those of the developed world; this process goes against Wilson (2007), Heese (2005), and Jamali and Mirshak (2007), who state that sustainability practices are not fully evolved in emerging economies, as they are unable to withstand the CSR standards used in developed economies.

\subsection{Empirical findings of previous studies}

Evidence from a variety of empirical studies concludes that developed and developing economies demonstrate mixed results on the relationship between CSR and CFP.

Curran and Moran (2007) examined the capital market reaction to corporate entry and exit in the UK FTSE4Good Index for the period from 1999 to 2002. The results indicate that the market reacted positively when a firm was added and negatively when firms were excluded from the Index, though these findings were insignificant. Gladysek and Chipeta (2012) considered only the impact on the share returns of firms listing on the South African JSE SRI Index; they also found insignificant abnormal returns for the 2004 to 2009 period. The insignificant findings from both studies suggest that firms do not benefit from a raised share price if they are included in CSR indices. Becchetti et al. (2012) conduct their study in a US context and examined the Domini 400 Social Index. They found a significant negative effect on abnormal returns after exit announcements from the Domini 400 Social Index during the 1990 to 2004 sample period. This relationship was present when financial distress shocks and stock market seasonality were controlled for. The results mentioned above are just some of the mixed results attained in this area. A possible reason for the share price not being a clear indicator of the relationship between CSR activities and CFP is because not all SRI indices disclose why firms are added or deleted from their Index (Curran \& Moran, 2007). Had there been disclosure, it would have served as a better proxy for CSR. 
One must consider the sample size and different measurement approaches and methods when drawing conclusions from the results. Existing techniques involved samples that were too small, in which fewer than 30 firms were considered (Folger \& Nutt, 1975), and time periods that were too short (Alexander \& Buchholz, 1978). They also relied on content analysis (Abbott \& Monsen, 1979) and reputation indices (Folger \& Nutt, 1975), which, as mentioned earlier, involves some drawbacks. Lastly, the small sample of CSR firms was compared to control groups of a similar size. These studies failed to find a direct link between CSR and CFP.

Cochran and Wood (1984) improved these existing techniques by increasing the sample size and by using two time periods, large industry-specific control groups, and a key correlate with CSR - asset age - in their model. The average age of corporate assets was found to be highly correlated with a firm's social responsibility ranking. Firms with older assets tend to have lower CSR rankings. Cochran and Wood (1984) reasoned that 'older' firms may be less flexible in adapting to social change, the types of management that older firms attract may be different to those of 'younger' firms, and regulatory constraints may have been less severe in the time period when firms with older assets constructed plants. Overall weak support for a positive relationship between CFP and CSR was found. The exclusion of asset age could explain why no positive relationship was found in earlier studies.

Waddock and Graves (1997) found CSP to be positively related to prior CFP and believed that this finding can be supported by the 'Slack Resource Theory'. This theory asserts that the availability of financial and other (slack) resources to firms as a result of their better financial performance may result in these firms investing in areas related to social domains, such as employee and community relations and the environment (Jensen, 1986). They also found CSP to be positively related to future CFP, providing 'Good Management Theory' as an explanation. This theory asserts that the strong relationship between CSP and good management practice is a result of management paying more attention to CSP domains, which improves relationships with stakeholders and, thus, financial performance (Freeman, 1984).

McWilliams and Siegel (2000) argued that the study by Waddock and Graves (1997) is misspecified, as they failed to control for Research and Development (R\&D) intensity. R\&D was found to be significantly positively related to financial performance. McWilliams and Siegel (2000) stated that R\&D investments lead to knowledge enhancement, resulting in product and process innovation, which enhances a firm's productivity. The inclusion of $R \& D$ resulted in a neutral relationship between CSR and financial performance (McWilliams \& Siegel, 2000). Aras et al. (2009) conducted a study in developing economies and found the same results as McWilliams and Siegel (2000) after controlling for R\&D intensity.

Based on the above literature review, it can be seen that there is no real consensus as to the nature of the relationship between CSR and CFP. This could be a result of the incorrect specification of CSR and CFP, as well as the failure to account for key variables that facilitate this relationship. This study will attempt to account for the key variables affecting CSR and CFP.

\section{Methodology}

\subsection{Sampling and data collection}

Firms that appear to be most sensitive to social responsibility issues are the firms that are JSE SRI Index compliant. To compare the financial performance of these firms to less socially responsible firms, firms that are not JSE SRI Index compliant but listed on the JSE ALSI will be selected to represent less socially responsible firms; this does not imply that these firms do not engage in CSR. Data for the JSE SRI Index is only available from 2004, which was the year in which the index was launched; hence, the period of the study will run from 2004 to 2013 inclusive, a total of 10 years.

CFP will be measured using accounting- and market-based indicators. The relevant accounting data for each firm considered will be obtained from the McGregorBFA database and computed as an annual value for each year considered. Market-based financial performance will be measured by stock returns. JSE daily closing share prices will be obtained from the McGregorBFA database.

The number of firms examined for the short-term entry announcement event study will range from 40 to 82 for the years from 2004 to 2013. Firms that delisted or had no publicly available information for the period will be excluded. The number of firms examined for 
the short-term exit announcement event study will range from 1 to 9 for the years 2005 to 2009 and 2011 to 2013 . The years 2004 and 2010 will be excluded, as there were no exclusions from the index.

The long-term study focuses on the Financials, Industrials, Consumer Services and Basic Materials industries. The Consumer Goods, Healthcare, Telecommunications and Technology industries will not be represented, as these industries comprise too few firms. The total sample of firms that will be considered is 42 .

\subsection{Description of overall research design}

Regarding objective one, to assess the effect that CSR has on CFP in the short-term, short-term performance will be determined in financial markets by the stock return performance over time, where the event will be the annual announcement of JSE SRI Index constituents. The sample period will be October 2004 to December 2013. A few assumptions must be made before employing the event study methodology (Gladysek \& Chipeta, 2012):

- Market agents do not anticipate the announcement.

- No confounding effects during the event window are analyzed.

Daily abnormal share returns will be a proxy for shortterm CFP, and the SRI Index will proxy for CSR. The event window will consist of 20 days prior to the announcement date (time $\mathrm{T}_{0}$ ) and 20 days following the announcement date. Therefore, the event window will consist of 41 days. This event window is sufficient enough to capture any leakage of information prior to $\mathrm{T}_{0}$ (Becchetti et al., 2012). It also gives investors enough time to react to the news, as some investors may be latecomers to the announcement (Gladysek \& Chipeta, 2012). Logarithmic share returns will be calculated, with expected returns proxied by the JSE SRI Index return. Returns will be computed from 20 trading days prior to the announcement date to 20 trading days after the announcement date $(-20,+20)$. Abnormal returns will then be defined as the difference between the share return and index return. Should the announcement of the SRI constituents have an effect on the market, abnormal returns will change to reflect this new information.

The JSE announces the new constituents of the SRI Index on $26^{\text {th }}$ November each year; hence, the announcement date will be the $26^{\text {th }}$ of November for the years considered in this study. Share returns can be noisy, and thus, abnormal returns will be averaged:

$$
A A R_{t}=\sum \frac{A R_{i t}}{N}
$$

where $A R_{i t}$ is the abnormal return of share $i$ at time $t$ and $N$ is the number of firms in the sample for the given year. The significance of the abnormal returns will be tested with Student's t test.

Objective two investigates the effect of CSR on CFP in the long term. An Ordinary Least Squares (OLS) regression model will be employed to explain the relationship between CSR and CFP:

$C F P_{i t}=\beta_{0}+\beta_{1} C S P_{i t}+\beta_{2}$ Firm_Size $_{i t}+\beta_{3}$ Risk $_{i t}$

Where

$i=1 \ldots N$ (number of firms)

$C F P=R O A, R O E, E P S$

$C S P=0$ or 1

Firm_Size $=\ln ($ Market Capitalization $)$

Risk $=\frac{\text { Long }- \text { Term Debt }}{\text { Total Assets }}$

For the purposes of this study, CSP will be a proxy for CSR of a particular firm, which is the independent variable. CSP is defined as a dummy variable $(0,1)$, as no quantifiable measure of the SRI Index exists, nor is information on the ranking of the constituents publically available in South Africa. CSP is 1 if a firm is included in the JSE SRI Index for a given year and 0 if it is not included but listed on the JSE ALSI (McWilliams \& Siegel, 2000).

$\mathrm{CFP}_{\text {it }}$ represents the corporate financial performance of firm $i$ in the long term, which is the dependent variable that will be captured by the following effective accounting metrics: Return on Assets (ROA), Return on Equity (ROE) and Earnings per share (EPS). These profitability ratios have been used in numerous empirical studies of this nature to capture corporate financial performance.

Comparisons across firms will be more accurate when using these accounting ratios, as financial leverage and the influences of risk on CFP will be included 
in the model (Cochran \& Wood, 1984). Each financial performance measure will be separately regressed on the independent and additional explanatory variables, such as firm size and risk. These firm- and industryspecific differences must be included, as they have been shown to be related to CFP and CSR in prior empirical research (Ullman 1985).

Burke et al. (1986) explains that larger firms attract more attention from external constituents and need to respond more openly to stakeholder demands, which is why they disclose their CSR behavior more often than smaller firms. Perrini et al. (2007) provide evidence that larger firms have a tendency to participate more in environmental management practices than small to medium-sized firms, as large firms are more likely to identify relevant stakeholders and meet their specific requirements through various CSR strategies. To control for size, the natural logarithm of market capitalization will be used (Aras et al., 2009).

In order to account for the influence of risk, the ratio of long-term debt to total assets will be used. Previous empirical works have found a significant negative relationship between firm performance and the level of debt. Waddock and Graves (1997) reason that risk must be explained, as management's risk tolerance influences its attitude toward activities that have the potential to elicit savings, incur future and present costs, and build or destroy markets.

R\&D intensity must be included to avoid a misspecified model, as it captures the effect of innovative activity on a firm's performance, considering that the various dimensions of CSR can create process and product innovation (McWilliams \& Siegel, 2000). Waddock and Graves (1994) find that the differences in R\&D intensity across industries have an impact on the performance of these industries. Separating the firms into industries as mentioned above will take these differences in R\&D intensity into account. It will also account for differences due to industry-level factors, such as economies of scale and competitive intensity, which must be explained (McWilliams \& Siegel, 2000). Industries will be determined in accordance with the Industry Classification Benchmark (ICB), which is the global standard for industry sector analysis that the JSE uses. This study will divide firms into different industries and thereafter run regressions for the firms within each industry. The model will be estimated using E-views.

\section{Discussion of results}

\subsection{Objective one}

\subsubsection{Entry announcements of the JSE SRI Index}

Table 1 displays the descriptive statistics. The standard deviations are relatively low and similar for all years except 2008 and 2013, which exhibit the highest standard deviations. The year 2009, however, exhibited the lowest standard deviation. The years 2008, 2009 and 2013 will be probed further to find possible explanations for these findings.

The announcement date for the SRI Index constituents was the $26^{\text {th }}$ of November 2008, 2009 and 2013. The increased risk in 2008 can be explained by the well-documented global financial crisis of 2008, which peaked around the announcement date that year (Naudè, 2009). Regarding the increased risk for 2013, the leading indicators around November in 2013 deteriorated. The global economic environment continued to improve around this time, suggesting that the sluggishness of the South African economy was caused mainly by domestic circumstances. The minimal risk experienced in 2009 could be justified by the expansion of the mining sector. At the time, sales for the mining sector were flourishing, and the country's diamond-mining industry became the fourth largest in the world. The SRI Index is dominated by this industry, and at this time, there was no labor unrest. Another possible explanation is that the overall construction sector had grown by $7.8 \%$ due to infrastructure expenditures for the 2010 Soccer World Cup. This industry is fairly represented in the SRI Index. The extreme minimum and maximum values of 2008 and 2013 are $(-0.0392,0.0305)$ and $(-0.0090$, $0.0136)$, respectively. These values characterize the increased volatility of returns during these periods, when the business cycle was in its trough phase (Gladysek \& Chipeta, 2012).

For years 2007 through 2009, mean returns were negative, reflecting the recessionary period. The skewness measures were slightly negative for all years except 2006 and 2009, which showed slight positive skewness. This indicates that our returns are slightly skewed, as opposed to being symmetric in the case of normal distribution. The return distribution appears to be slightly leptokurtic for 2007 and 2010. The other 
Table 1. Descriptive Statistics

\begin{tabular}{lcccccccccc}
\hline \multicolumn{1}{c}{ Descriptive Statistics } \\
\hline & $\mathbf{2 0 0 4}$ & $\mathbf{2 0 0 5}$ & $\mathbf{2 0 0 6}$ & $\mathbf{2 0 0 7}$ & $\mathbf{2 0 0 8}$ & $\mathbf{2 0 0 9}$ & $\mathbf{2 0 1 0}$ & $\mathbf{2 0 1 1}$ & $\mathbf{2 0 1 2}$ & $\mathbf{2 0 1 3}$ \\
\hline Mean & 0.0010 & -0.0001 & 0.0011 & -0.0004 & -0.0019 & -0.0002 & 0.0010 & 0.0003 & 0.0024 & 0.0005 \\
Median & 0.0009 & 0.0003 & 0.0003 & 0.0002 & 0.0006 & -0.0003 & 0.0023 & 0.0011 & 0.0032 & 0.0046 \\
Maximum & 0.0071 & 0.0083 & 0.0118 & 0.0129 & 0.0306 & 0.0060 & 0.0134 & 0.0111 & 0.0137 & 0.0519 \\
Minimum & -0.0053 & -0.0111 & -0.0077 & -0.0164 & -0.0392 & -0.0064 & -0.0193 & -0.0175 & -0.0091 & -0.0475 \\
Std. Dev. & 0.0029 & 0.0044 & 0.0049 & 0.0065 & 0.0185 & 0.0028 & 0.0071 & 0.0072 & 0.0061 & 0.0266 \\
Skewness & -0.1240 & -0.1351 & 0.1908 & -0.4863 & -0.3728 & 0.1162 & -0.7230 & -0.6098 & -0.2716 & -0.0107 \\
Kurtosis & 2.3991 & 2.6948 & 2.3590 & 3.0263 & 2.2808 & 2.4977 & 3.4074 & 2.8991 & 2.1353 & 2.1567 \\
& & & & & & & & & & \\
Jarque-Bera & 0.7219 & 0.2838 & 0.9505 & 1.6169 & 1.8333 & 0.5233 & 3.8556 & 2.5585 & 1.7813 & 1.2156 \\
Probability & 0.6970 & 0.8677 & 0.6217 & 0.4456 & 0.3999 & 0.7698 & 0.1455 & 0.2783 & 0.4104 & 0.5445 \\
\hline
\end{tabular}

years have slightly platykurtic distributions. On this basis, it is evident that returns appear to display some minor non-normality. However, by formally testing the normality assumption of the return distribution with the null hypothesis and jointly testing for skewness and kurtosis $\left(\mathrm{H}_{0}: \mathrm{S}=0\right.$ and $\left.\mathrm{K}=3\right)$ at the $95 \%$ confidence level, the Jarque-Bera probability values are greater than 0.05 for all years, indicating that the null hypothesis, which states that the series is normally distributed, fails to be rejected.

The figures below illustrate the Average Abnormal Rates (AARs) for the entrants to the SRI Index for the years 2004 through 2013. As shown in Figure 1, years 2004 and 2005 had declining AARs just before the announcement date and increase just after the announcement date. Moving to years 2006 and 2007, the AARS showed a sharp increase two days before the announcement date. There was a decrease for a few days after the announcement, before an increase in AARs occurred again. In 2008, there was a sharp decline with an increase just before the announcement date. After the announcement date, there was a slight continuation of the incline before the AARs dropped.

A stationary time series is a series whose properties remain constant over time. Many financial series, such as share prices, appear to be non-stationary, and new statistical issues arise when analyzing non-stationary data. The unit root tests (Augmented Dickey-Fuller (ADF) Phillips-Perron (PP)) and stationarity test (Kwiatkowski-Phillips-Schmidt-Shin (KPSS)) provide sufficient evidence to conclude that the AARs are stationary for firms included in the Index. The results are available upon request.

Figure 2 displays the AARs for 2009 to 2013. Abnormal returns for the years 2009 to 2012 hovered around zero, with 2013 displaying great volatility and the highest positive and negative abnormal returns. The volatility in 2013 could be attributed to economic uncertainty in the country. A possible explanation for this may be South Africa's poor growth in 2013, which was largely due to increased strike activity and its impact on the economy. Before the announcement date, the years 2009 to 2012 displayed decreased AARs, with 2013 displaying a sharp decline and a slight increase. After the announcement date, the same trend was observed, with the years 2009, 2010 and 2012 decreasing and 2013 increasing; however, 2011 showed a slight decline followed by an increase.

The year 2004 experienced minimal declines in AARs. Gladysek \& Chipeta (2012) propose the short-lived shareholder interest in the index as an explanation. The years 2008 and 2013 experienced the most significant increases and decreases. Significant results represent daily 


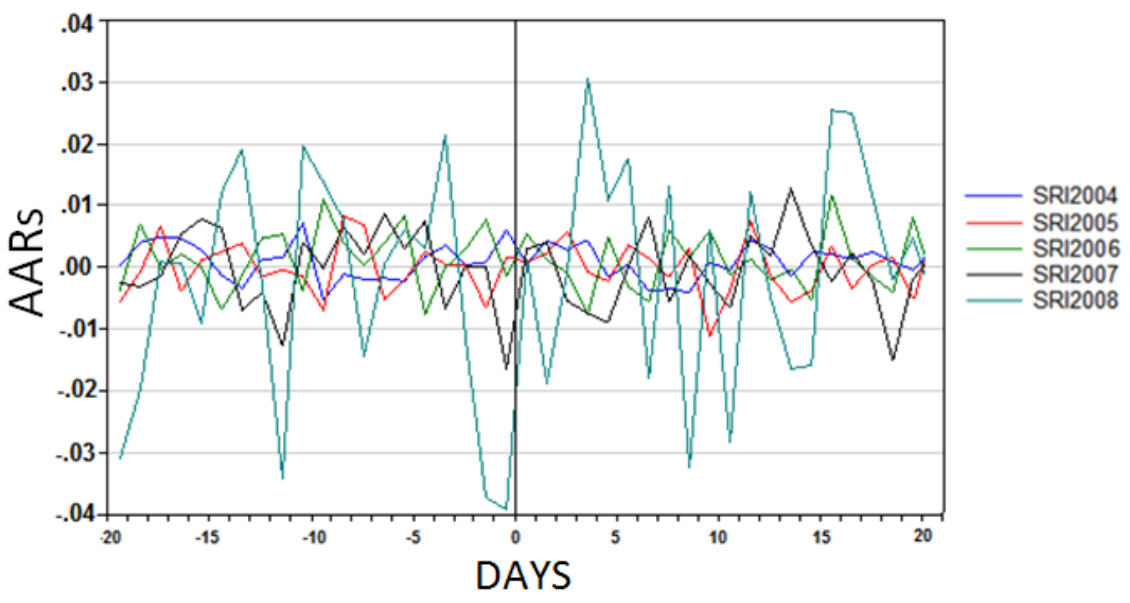

Figure 1. Average Abnormal Returns for the JSE SRI Index for 2004 to 2008

Note: Average abnormal returns observed from 20 days prior the announcement date to 20 days post-announcement date (41-day event window). ARRs are not representative of percentages.

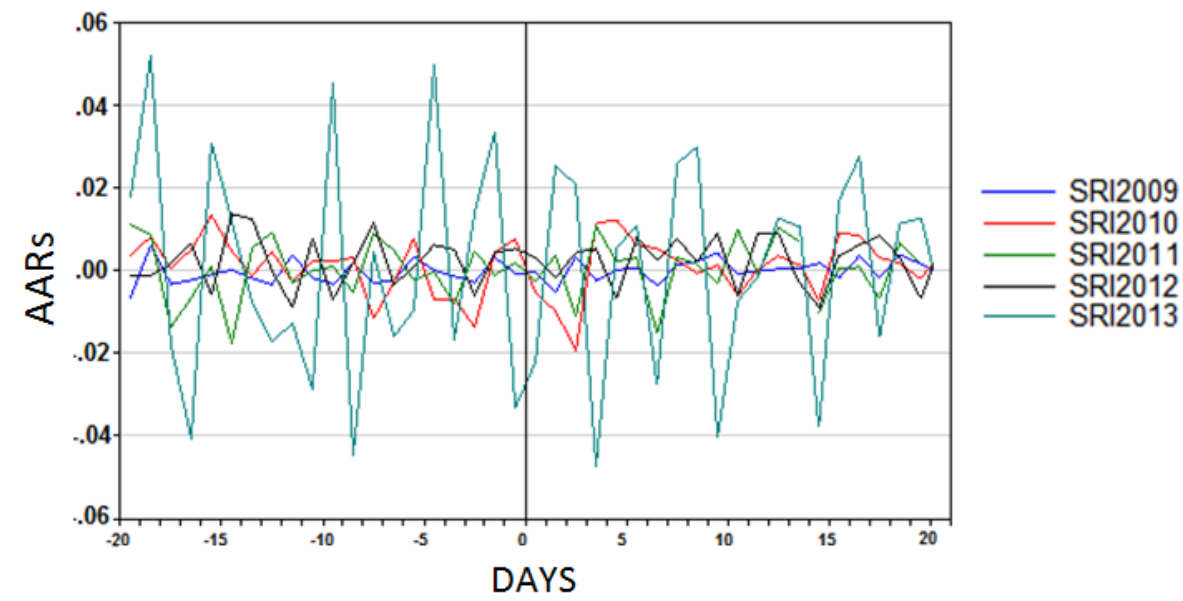

Figure 2. Average Abnormal Returns for the JSE SRI Index for 2009 to 2013 
Table 2. Parametric Tests

\begin{tabular}{llc}
\hline & \multicolumn{2}{c}{ Students t Test } \\
\cline { 2 - 3 } 2004 & Statistic & P-value \\
2005 & 2.0957 & $0.0425^{* *}$ \\
2006 & -0.1249 & 0.9012 \\
2007 & 1.4279 & 0.1611 \\
2008 & -0.3731 & 0.7110 \\
2009 & -0.6575 & 0.5146 \\
2010 & -0.3944 & 0.6954 \\
2011 & 0.9171 & 0.3646 \\
2012 & 0.2774 & 0.7829 \\
2013 & 2.5451 & $0.0149^{* *}$ \\
\hline
\end{tabular}

Note: ${ }^{*}, * * * * *$ indicates significance at $0.01,0.05$ and 0.10 , respectively.

AARs, which were greater than $2.5 \%$ and less than $-2.5 \%$ (MacKinlay, 1997). The annual announcement of JSE SRI constituents will be perceived as good news should the daily AARs exceed $2.5 \%$. When AARs are less than $-2.5 \%$, the announcement will be perceived as bad news. Therefore, from the figures above, it can be seen that 2008 and 2013 carried both good and bad news.

For the rest of the years studied (2004 to 2007 and 2009 to 2012), the AARs fell within the $(-2.5 \%,+2.5 \%)$ limits. This suggests that the market perceives JSE SRI constituent announcements as no news, confirming the findings of Gladysek and Chipeta's (2012) study covering the years 2004 through 2008. The finding of a market reaction in 2008 could be substantiated by the growth of the SRI Index; thus, trading volume had increased. Failure to find a market reaction prior to 2008 and between 2009 and 2012 could reflect that potential investors were still unaware of the index or were falsely advised that an SRI Index will generate a return below that of a general index (Gladysek \& Chipeta, 2012). As the years progressed, it is possible that the SRI Index became more widely known, allowing for significant share price movements to be realized around the announcement date. Thus, the results for 2008 and 2013 provide evidence that socially responsible investing is slowly affecting the South African market over time.
Parametric one-sample $t$ tests were run in order to determine the significance of the AARs for the 2004 to 2013 period. Table 2 shows the results for firms included in the index. The AARs for all years except 2004 and 2012 had insignificant p-values. Therefore, based on these results, the null hypothesis that firms that announced their inclusion in the JSE SRI Index are associated with no significant share price changes fails to be rejected at the $95 \%$ confidence interval for all years except 2004 and 2012. These two years are significant at the $95 \%$ confidence interval and are associated with positive mean values, indicating that the null hypothesis is rejected and that firms that announced their inclusion in the JSE SRI Index are associated with significant positive share price changes. The direction of the AARs was positive for six of the ten years (2004, 2006, 2010, 2011, 2012 and 2013) and insignificant for the other four years; this result may nevertheless suggest that the announcements of firms included in the JSE SRI Index may be associated with positive share price changes for those firms.

\subsubsection{Exit announcements of the JSE SRI Index}

As shown in Table 3, the years 2008 and 2012 were associated with the highest risk. This result may be due to the poor state of the South African economy at the 
Table 3. Descriptive Statistics

\begin{tabular}{lcccccccc}
\hline \multicolumn{7}{c}{ Descriptive Statistics } \\
\hline & $\mathbf{2 0 0 5}$ & $\mathbf{2 0 0 6}$ & $\mathbf{2 0 0 7}$ & $\mathbf{2 0 0 8}$ & $\mathbf{2 0 0 9}$ & $\mathbf{2 0 1 1}$ & $\mathbf{2 0 1 2}$ & $\mathbf{2 0 1 3}$ \\
\hline Mean & 0.0004 & -0.0006 & -0.001913 & -0.0003 & 0.0003 & 0.0005 & -0.0013 & -0.0016 \\
Median & -0.0003 & -0.0014 & 0.000283 & 0.0020 & 0.0037 & -0.0003 & -0.0033 & -0.0008 \\
Maximum & 0.0167 & 0.0180 & 0.04793 & 0.0652 & 0.0282 & 0.0281 & 0.1185 & 0.0098 \\
Minimum & -0.0158 & -0.0205 & -0.047373 & -0.0732 & -0.0291 & -0.0248 & -0.1430 & -0.0152 \\
Std. Dev. & 0.0088 & 0.0104 & 0.018019 & 0.0285 & 0.0127 & 0.0124 & 0.0465 & 0.0059 \\
Skewness & 0.0828 & 0.0264 & -0.130365 & -0.3260 & -0.4492 & 0.0801 & -0.2486 & -0.3681 \\
Kurtosis & 2.2972 & 2.3351 & 3.468121 & 3.4409 & 3.0195 & 2.2789 & 4.6365 & 3.3648 \\
& & & & & & & & 0.95972 \\
Jarque-Bera & 0.8906 & 0.7600 & 0.490492 & 1.0582 & 1.3797 & 0.9322 & 4.1533 \\
Probability & 0.6406 & 0.6839 & 0.782512 & 0.5891 & 0.5017 & 0.6274 & 0.0822 & 0.5618 \\
\hline
\end{tabular}

time brought about by the global financial crisis of 2008 and the Eurozone debt crisis of 2011, which did not abate by 2012 . However, in sharp contrast to our findings for entry announcements, the year 2013 was associated with the lowest risk. For the other years, the standard deviations are relatively similar. The JarqueBera probabilities reflect normal distributions for all years except 2012 at the $90 \%$ confidence interval. The skewness is minimal, and the kurtosis values are not very far off from 3 for a normal distribution for all years, with the exception of 2012.

As seen in Figure 3, 2005 was associated with an increase in AARs before the announcement date. After the announcement date, the AARs continued to increase before decreasing. The year 2006 exhibited some volatility in AARs. There was an increase before the announcement date, but after the announcement date, there was a sharp decline. The AARs for the years 2007 and 2008 displayed high volatility. For the year 2007, the AARS increased before the announcement date, in contrast to 2008, when there was a decline. However, after the announcement date, the AARs began declining for 2007 but began to increase for 2008 .

Figure 4 displays the AARs for 2009, 2011, 2012 and 2013. The AARs for the years 2009, 2011 and 2013 are concentrated around zero, with 2012 displaying large variations. An explanation for these variations could be the vast amount of labor unrest that plagued South Africa in 2012. These unrests originated from the platinum mining sector and spread to other sectors of the economy. An important note to consider is that only one firm exited the Index in 2012, Hulamin (an aluminum-mining firm), which could further explain the variations.

Applying MacKinlay's (1997) definition of significant AARs, the years 2007, 2008 and 2012 experienced the most significant declines and inclines. From Figures 3 and 4, it can be seen that these years carried bad news, displaying decreases greater than $2.5 \%$, and good news, displaying increases greater than $2.5 \%$. The years 2005, 2006, 2009, 2011 and 2013 were perceived as having no news, as they fell within the limits of $-2.5 \%$ and $2.5 \%$. As explained above, a possible explanation for why the earlier years had no news could be the thin trading volume of the index caused by investors being unaware of the index or under the impression that the JSE SRI Index generates lower returns than general indices, such as the ALSI.

For firms that were excluded from the index, Table 4 shows that the AARs for seven out of eight years have insignificant $\mathrm{p}$-values, implying that these AARs are equal to zero. The year 2013 is significant at the $90 \%$ 


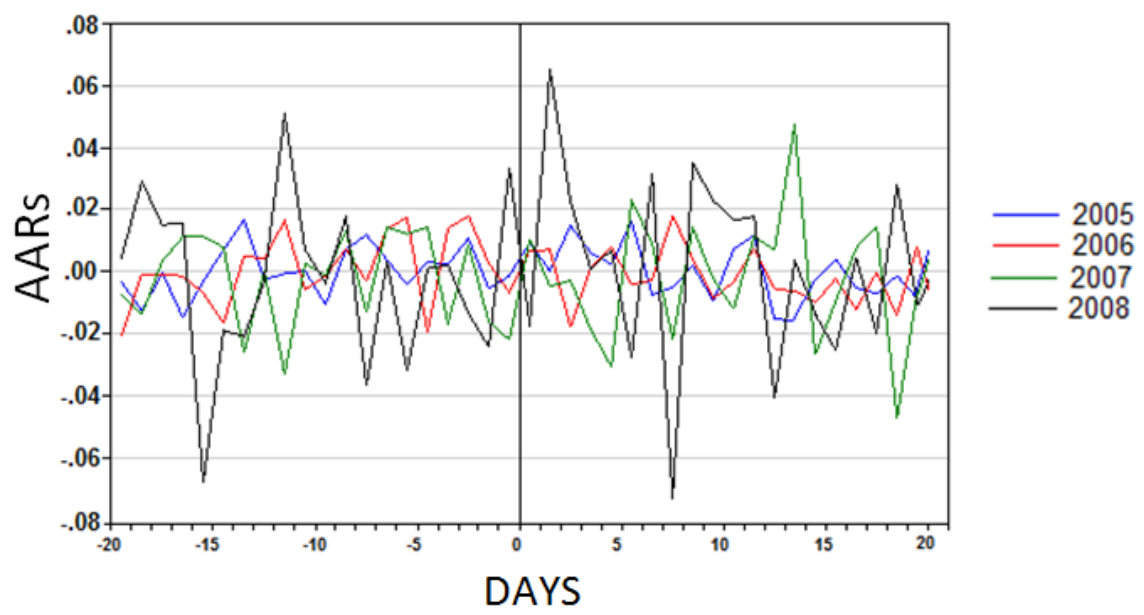

Figure 3. Average Abnormal Returns for the JSE SRI Index for 2005 to 2008

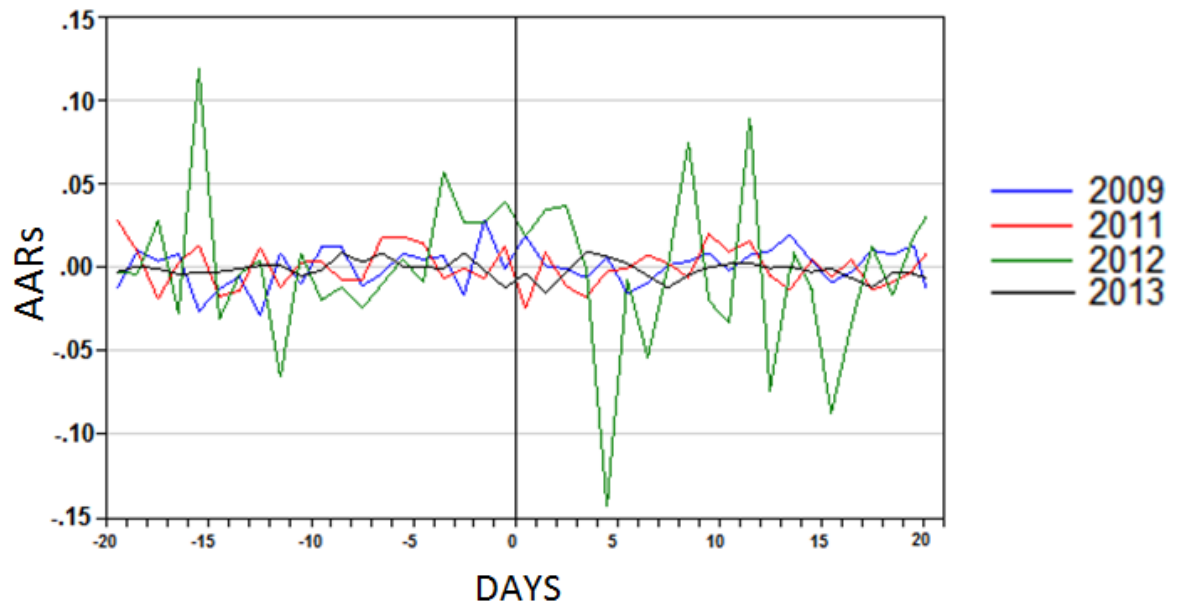

Figure 4. Average Abnormal Returns for the JSE SRI Index for 2009 to 2013 
Table 4. Parametric Tests

\begin{tabular}{lll}
\hline & \multicolumn{2}{c}{ Students t Test } \\
\cline { 2 - 3 } & Statistic & P-value \\
\hline 2005 & 0.2758 & 0.7841 \\
$\mathbf{2 0 0 6}$ & -0.3657 & 0.7165 \\
$\mathbf{2 0 0 8}$ & -0.6799 & 0.5005 \\
$\mathbf{2 0 0 9}$ & -0.0769 & 0.9391 \\
$\mathbf{2 0 1 1}$ & 0.1750 & 0.8620 \\
$\mathbf{2 0 1 2}$ & 0.2369 & 0.8139 \\
$\mathbf{2 0 1 3}$ & -0.1737 & 0.8630 \\
\hline
\end{tabular}

Note: ${ }^{*}{ }^{* *},{ }^{* * *}$ indicates significance at $0.01,0.05$ and 0.10 , respectively.

confidence interval, suggesting that investors perceive the exclusion of firms from the index as negative information. The direction of the AARs for five of the eight years was negative (2006, 2007, 2008, 2012 and 2013), and although four years showed insignificant AARs, this result nevertheless suggests that the announcements of firms excluded from the JSE SRI Index may be associated with negative share price changes for those firms.

\subsection{Objective two}

Three financial ratios were used to analyze the financial performance of firms in relation to their social responsibility measures.

The purpose of the regression analysis is to test whether CSR is significantly associated with superior or inferior financial performance within industry groups. The finding of a significant positive relationship may suggest that CSR activities by firms should be increased to produce better implications for firm performance. A leading CSR firm that derives the following benefits highlights why these activities may be characterized by higher financial performance: relationships with stakeholders improve, management of brand and reputation may be more effective, attraction and retention of highcaliber employees may be promoted, and the organization may receive recognition for displaying a high degree of ethical standards (Freeman, 1984; Orlitzky et al., 2003; Waddock \& Graves, 1997).
A negative relationship may be explained by the additional costs of undertaking CSR activities that do not enhance or contribute to shareholder value. As a firm becomes more socially responsible, the more difficult it becomes for the firm to increase its economic profits, as it cannot readily engage in projects without assessing their implications for ESG frontiers.

Two possible reasons for why there may be weak support (a neutral effect) for a link between CSP and CFP include the reliability of accounting figures, as some firms manipulate financial statements, and the notion that non-constituents cannot systematically experience weaker performance, as Lee, Faff and Smith (2009) highlight that these firms stand a chance of being liquidated or acquired by market leaders or adjusting their CSR practices in order to maximize their economic profit. Lee et al., (2009) propose an interesting view on why no relationship may exist between CSR and CFP, emphasizing that the financial benefits available to leading CSR firms (in the context of this study, this would refer to JSE SRI constituents) may not be available to lagging CSR firms (non-constituents). However, these lagging CSR firms may have an advantage over leading CSR firms, as they are not constrained by their CSR practices and can thus accept profitable projects that leading CSR firms cannot. These two opposing effects may cancel each other out. 
Table 5. Correlation Matrix for the Dependent and Explanatory Variables

\begin{tabular}{lcccccc}
\hline Variable & EPS & RISK & ROA & ROE & SIZE & CSR \\
\hline EPS & 1.0000 & & & & & \\
RISK & -0.4280 & 1.0000 & & & & \\
ROA & -0.5289 & 0.4410 & 1.0000 & & & \\
ROE & -0.2863 & 0.1673 & 0.1743 & 1.0000 & & \\
SIZE & 0.5478 & -0.3979 & -0.7169 & -0.3260 & 1.0000 & \\
CSR & 0.6629 & -0.3170 & -0.8392 & -0.4074 & 0.9024 & 1.0000 \\
\hline
\end{tabular}

Table 6. Regressions for CSR and CFP

\begin{tabular}{lccc}
\hline \multirow{2}{*}{ Variable } & Regression 1 & Regression 2 & Regression 3 \\
\cline { 2 - 4 } Constant & EPS & ROE & ROA \\
\hline Risk & $(3608.5610$ & -6.2569 & $(46.5252)$ \\
& -791.0636 & $(76.7390)$ & 2.0142 \\
Size & $(632.3384)$ & 2.9960 & $(2.0752)$ \\
& -150.2255 & $(12.3813)$ & 10.6044 \\
CSR & $(174.8156)$ & 1.3368 & $(7.5065)$ \\
& $973.5138^{* * *}$ & $(3.4229)$ & $-18.1664^{* *}$ \\
F-Statistic & $(506.6335)$ & -9.3044 & $(6.0143)$ \\
N & 3.7154 & $(9.9200)$ & 10.6061 \\
\hline
\end{tabular}

Note: ${ }^{*}, * * * * *$ indicates significance at $0.01,0.05$ and 0.10 , respectively.

\subsubsection{Financial Industry}

The correlation matrix in Table 5 shows that CSR and ROA are negatively correlated. This finding should not be interpreted as evidence of a causal relationship between CSR and CFP. This result merely indicates that a relationship exists between these two variables of interest in this study. Size and CSR is positively correlated. This relationship is not surprising, as there is a widely held view that corporate responsibility will increase as firm size increases.
From Table 6, Regression 1 indicates that the CSR coefficient is positively related to financial performance and significant at the $90 \%$ confidence level. The overall model is significant at the $95 \%$ confidence level. This provides evidence that there is a significant difference in financial performance between constituents and non-constituents of the JSE SRI Index. Thus, the null hypothesis is rejected. For every one-unit increase in CSP, ceteris paribus, EPS increases by 973.5138 , which suggests that constituents will, on average, ex- 
Table 7. Regressions for CSR and CFP

\begin{tabular}{lcccc}
\hline & & Regression 1 & Regression 2 & Regression 3 \\
\hline Industry & Variable & EPS & ROE & ROA \\
\hline Basic Materials & CSR & -923.2763 & -7.9659 & -4.8856 \\
& & $(1349.7350)$ & $(43.4975)$ & $(27.5579)$ \\
Consumer Services & CSR & -244.3887 & $23.8777^{* * *}$ & 3.6215 \\
& & $(184.0593)$ & $(10.1479)$ & $(9.5511)$ \\
Industrials & CSR & 79.0387 & 3.3564 & 1.6271 \\
\end{tabular}

Note: ${ }^{*}, * * * *$ indicates significance at $0.01,0.05$ and 0.10 , respectively.

perience better financial performance than non-constituents. This result confirms Chand's (2006) paper, in which a positive association was found when controlling for industry.

Regression 2 suggests that CSP is negatively related to financial performance; however, this result is not significant nor is the model itself. This finding provides empirical evidence in favor of the hypothesis of no significant difference in financial performance between constituents and non-constituents of the JSE SRI Index. The can be interpreted to mean that CSP has a neutral effect on CFP. Similar results were achieved by McWilliams and Siegel (2001), who found this relationship to hold when R\&D was accounted for, and Lee et al. (2009), who concluded that the ROA and ROE performance measure showed no significant difference between leading CSP and lagging CSP firms.

Regression 3 supports the finding of Ulllman's (1985) study that CSR hurts financial performance. CSR is significantly related to CFP at the $95 \%$ confidence level. The model is significant as well. Based on this evidence, the null hypothesis that there is no significant difference in financial performance between constituents and non-constituents of the JSE SRI Index is rejected. For every one-unit increase in CSP, ceteris paribus, ROA will decrease by 18.16635 . The findings indicate that on average, constituents of the JSE SRI Index will underperform non-constituents financially by 18.16635 .

\subsubsection{Basic Materials, Consumer Services and Industrials Industries}

The results for the Industrials industry show that size is highly positively correlated to EPS and CSR. Both the Basic Materials and Industrials industries provide empirical evidence supporting the null hypothesis; thus, CSP has a neutral effect on CFP. Although both industries display insignificant results, the CSP coefficients are all positive for the Industrials industry and negative for the Basic Materials industry.

When analyzing the Consumer Services industry, a negative correlation between CSP and EPS is observed. A positive significant relationship is found between CSP and ROE at the $90 \%$ confidence interval. CSP is found to have an insignificant relationship with EPS and ROA, emphasizing that JSE SRI Index constituents do not manage their assets more effectively than nonconstituents.

\section{Conclusion}

The results of this study add to the body of literature on CSR and CFP. Very few studies have considered both entry and exit announcements using the JSE SRI Index. This study employs an event study methodology for the short-term and regression analysis for the longterm. The analysis in this study examines short-term shareholder wealth returns around announcement dates and makes a long-term comparison of the op- 
erating performance of JSE SRI constituents to that of non-constituents of the index.

The analyses in both parts to the study provide mixed evidence of the relationship between CSR and CFP. The event study methodology shows that investors are not rewarded when firms enter the index, as there are no significant share price movements realized for these firms, confirming the null hypothesis with the exception for the years 2004 and 2012. The findings for 2004 may be attributed to the short-lived enthusiasm for the launch of the index and the finding of significant share price movements in 2012 may be attributed to investors becoming more aware of the index. Investors earned significant positive abnormal returns by investing in the JSE SRI Index around the announcement date in 2004 and 2012. The study of firms exiting the Index indicates that investors were penalized in 2013, as firms experienced significant negative share price changes in this period, thus rejecting the null hypothesis in favor of the alternative hypothesis. Overall, it can de deduced that as the years progressed, the announcement event was considered as good and bad news entering the market.

The analysis over the long term also provides mixed results for CSR and CFP within the different industries. Within a particular industry, it is possible to find significant positive, negative and neutral differences in CFP between constituents and non-constituents of the JSE SRI Index; thus, the relationship between CSP and CFP may be sensitive to the type of CFP measure used. Therefore, it is uncertain whether JSE SRI Index compliance leads to significant differences in financial performance.

Future research could improve the long-term analysis by increasing the sample size of firms under consideration by looking at year-to-year changes as opposed to analyzing firms listed on the indices for the entire ten-year period. Another avenue to consider would be to include asset age in the regression analysis due to its importance, as previously mentioned. If the JSE were more explicit about the relative ranking of the firms on the JSE SRI Index, investors would be provided with a better understanding of CSR and why firms are included in and excluded from the index. This information would allow potential investors to include these considerations in their own investment portfolios.

\section{References}

Abbott, W. F., \& Monsen, R. J. (1979). On the Measurement of Corporate Social Responsibility: SelfReported Disclosures as a Method of Measuring Corporate Social Involvement. Academy of Management Journal, 22 (3), 501-515.

Alexander, G. J., \& Buchholz, R. A. (1978). Corporate Social Responsibility and Stock Market Performance. Academy of Management Journal, 21 (3), 479-486.

Aras, G., Aybars, A., \& Kutlu, O. (2009). Managing Corporate Performance: Investigating the Relationship between Corporate Social Responsibility and Financial Performance in Emerging Markets. International Journal of Productivity and Performance Management, 59 (3), 229-254.

Babalola, Y. A. (2012). The Impact of Corporate Social Responsibility on Firms' Profitability in Nigeria. European Journal of Economics, Finance and Administrative Sciences, 45, 39-50.

Bagnoli, M., \& Watts, S. G. (2003). Selling to Socially Responsible Consumers: Competition and the Private Provision of Public Goods. Journal of Economics \& Management Strategy, 12 (3), 419-445.

Balabanis, G., Phillips, H. C., \& Lyall, J. (1998).Corporate Social Responsibility and Economic Performance in The Top British Firms: Are They Linked? European Business Review, 98 (1), 25-44.

Baskin, J. (2006). Corporate Responsibility in Emerging Markets. The Journal of Corporate Citizenship, 24, 29-47.

Becchetti, L., Ciciretti, R., Hasan, I., \& Kobeissi, N. (2012). Corporate Social Responsibility and Shareholder's Value. Journal of Business Research, 65 (11), 1628-1635.

Burke, L., Logsdon, J. M., Mitchell, W., Reiner, M, \& Vogel D. (1986). Corporate Community Involvement in the San Francisco Bay Area. California Management Review, 28 (3), 122-141.

Chand, M. (2006). The Relationship between Corporate Social Performance and Corporate Financial Performance: Industry Type as a Boundary Condition. The Business Review, 5 (1), 240-245.

Choi, J., Kwak, Y., \& Choe, C. (2010). Corporate Social Responsibility and Corporate Financial Performance: Evidence from Korea. Australian Journal of Management, 35 (3), 291-311. 
Cochran, P. L., \& Wood, R. A. (1984). Corporate Social Responsibility and Financial Performance. Academy of Management Journal, 27 (1), 42-56.

Crisóstomo, V. L., Freire, F., S., \& de Vascincellos, F. C. (2011). Corporate Social Responsibility, Firm Value and Financial Performance in Brazil. Social Responsibility Journal, 7 (2), 295-309.

Curran, M. M., \& Moran, D. (2007).Impact of the FTSE4Good Index on Firm Price: An Event Study. Journal of Environmental Management, 82 (4), 529-537.

De Cleene S., \& Sonnenberg, D. (2004). Socially Responsible Investment in South Africa (2nd ed.). Johannesburg: African Institute of Corporate Citizenship.

Folger, H. R., \& Nutt, F. (1975). A Note on Social Responsibility and Stock Valuation. Academy of Management Journal, 18 (1), 155-159.

Freeman, R. E. (1984). Strategic Management: A Stakeholder Approach. Boston, MA: Pitman.

Friedman, M. (1970, September 13). The Social Responsibility Of Business Is To Increase Its Profits. New York Times, 13, 122-126.

Gladysek, O., \& Chipeta, C. (2012).The Impact of Socially Responsible Investment Index Constituent Announcements on Firm Price: Evidence from the JSE. South African Journal of Economic and Management Sciences, 15 (4), 429-439.

Heal, G. (2008). When Principles Pay: Corporate Social Responsibility and the Bottom Line. New York, NY: Columbia University Press.

Heese, H. (2005). The Development of Socially Responsible Investment in South Africa: Experience and Evolution of SRI in Global Markets. Development Southern Africa, 22 (5), 729-739.

Heinze, D. C. (1976). Financial Correlates of a Social Involvement Measure. Akron Business and Economic Review, 7 (1), 48-51.

Hopkins, M. (2003). The Planetary Bargain: Corporate Social Responsibility Matters. London, UK: Earthscan Publications Ltd.

Jamali, D., \& Mirshak, R. (2007). Corporate Social Responsibility (CSR): Theory and Practice in a Developing Country Context. Journal of Business Ethics, 72 (3), 243-262.

Jensen, M., C. (1986). The Agency Costs of Free Cash Flow: Corporate Finance and Takeovers. American Economic Review, 76 (2), 323-329.
Johannesburg Stock Exchange. (2010). SRI Index Brochure. Retrieved from https://www.jse.co.za/services/market-data/indices/socially-responsibleinvestment-index

Lee, D. D., Faff, R. W., \& Smith, K. (2009). Revisiting the Vexing Question: Does Superior Corporate Social Performance Lead to Improved Financial Performance? Australian Journal of Management, 34 (1), 21-50.

Lin, C. H., Yang, H. L., \& Liou, D. H. (2009). The Impact of Corporate Social Responsibility on Financial Performance: Evidence from Business in Taiwan. Technology in Society, 31 (1), 56-63.

MacKinlay, A. C. (1997). Event Studies in Economics and Finance. Journal of Economic Literature, 35 (1), 13-39.

McGuire, J., Schneeweis, T., \& Hill, J. (1986). An analysis of alternative measures of strategic performance. Advances in strategic management, 4 (2), 127-154.

McWilliams, A., \& Siegel, D. (2000). Corporate Social Responsibility and Financial Performance: Correlation or Misspecification? Strategic Management Journal, 21 (5) 603-609.

McWilliams, A. \& Siegel, D. (2001). Corporate Social Responsibility: A Theory of the Firm Perspective. The Academy of Management Review, 26 (1), $117-127$

Moskowitz, M. (1972). Choosing Socially Responsible Stocks. Business and Society Review, 1 (1), 71-75.

Naudè, W. (2009). The Financial Crisis of 2008 and the Developing Countries (Discussion Paper No. 2009/01). United Nations University. World Institute for Development Economics Research.

Orlitzky, M., Schmidt, F., \& Rynes, S. (2003). Corporate Social and Financial Performance: A MetaAnalysis. Organization Studies, 24 (3), 403-441.

Perrini, F., Russo, A., \& Tencati, A. (2007). CSR Strategies of SMEs and Large Firms. Evidence from Italy. Journal of Business Ethics, 74 (3), 285-300.

Preston, L. E. (1990). Stakeholder Management and Corporate Performance. Journal of Behavioral Economics, 19 (4), 361-375.

Preston, L. E., \& O’Bannon, D. P. (1997). The Corporate Social-Financial Performance Relationship: A Typology and Analysis. Business and Society, 36 (4), 419-429. 
Spicer, B. H. (1978). Investors, Corporate Social Performance and Information Disclosure: An Empirical Study. Accounting Review, 53 (1), 94-111.

Tsoutsoura, M. (2004). Corporate Social Responsibility and Financial Performance (Working Paper). University of California at Berkeley.

Ullman, A. (1985). Data In Search of a Theory: A Critical Examination of the Relationship among Social Performance, Social Disclosure, and Economic Performance. Academy of Management Review, 10 (3), 540-577.

Vance, S. C. (1975). Are Socially Responsible Corporations Good Investment Risks? Management Review, 64 (8), 18-24.

Waddock, S. A., \& Graves, S. B. (1997). The Corporate Social Performance-Financial Performance Link. Strategic Management Journal, 18 (4), 303-319.

Wilson, T. (2007). No, Really - What Are The 'Equator Principles'? The Institute of Public Affairs Review, 59 (2), 7-10. 


\section{Appendix}

The tables below depict the correlation matrices and regression results for the Basic Materials, Consumer Services and Industrials industries.

\section{Basic Materials Industry}

Table A1. Correlation Matrix for the Dependent and Explanatory Variables

\begin{tabular}{|c|c|c|c|c|c|c|}
\hline Variable & EPS & ROA & ROE & RISK & SIZE & CSR \\
\hline EPS & 1 & & & & & \\
\hline ROA & 0.792253 & 1 & & & & \\
\hline ROE & 0.799943 & 0.994396 & 1 & & & \\
\hline RISK & -0.15004 & -0.10499 & -0.137 & 1 & & \\
\hline SIZE & 0.560989 & 0.164708 & 0.170279 & 0.088631 & 1 & \\
\hline CSR & 0.116712 & 0.014035 & 0.007743 & 0.298992 & 0.576056 & 1 \\
\hline
\end{tabular}

Table A2. Regressions for CSR and CFP

\begin{tabular}{lccc}
\hline \multirow{2}{*}{ Variable } & Regression 1 & Regression 2 & Regression 3 \\
\cline { 2 - 4 } Constant & EPS & ROE & ROA \\
\hline Risk & -11243.5300 & -79.6600 & -44.7631 \\
& 6133.7420 & 197.6701 & 125.2343 \\
Size & -1751.2320 & -43.5070 & -20.7053 \\
& 3965.2670 & 127.7873 & 80.9599 \\
CSR & $538.9705^{* * *}$ & 4.4637 & 2.6935 \\
F-Statistic & 270.0136 & 8.7016 & 5.5129 \\
N & -923.2763 & -7.9659 & -4.8856 \\
\hline
\end{tabular}

Note: ${ }^{*}{ }^{* *},{ }^{* * *}$ indicates significance at $0.01,0.05$ and 0.10 , respectively. 


\section{Consumer Services Industry}

Table A3. Correlation Matrix for the Dependent and Explanatory Variables

\begin{tabular}{|c|c|c|c|c|c|c|}
\hline Variable & EPS & ROA & ROE & SIZE & RISK & CSR \\
\hline EPS & 1 & & & & & \\
\hline ROA & -0.66214 & 1 & & & & \\
\hline ROE & -0.60698 & 0.512261 & 1 & & & \\
\hline SIZE & 0.372829 & -0.48496 & -0.20033 & 1 & & \\
\hline RISK & 0.10573 & 0.163541 & -0.35875 & 0.309039 & 1 & \\
\hline CSR & -0.40445 & 0.099984 & 0.598215 & 0.094794 & 0.095371 & 1 \\
\hline
\end{tabular}

Table A4. Regressions for CSR and CFP

\begin{tabular}{|c|c|c|c|}
\hline \multirow{2}{*}{ Variable } & Regression 1 & Regression 2 & Regression 3 \\
\hline & EPS & ROE & ROA \\
\hline \multirow[t]{2}{*}{ Constant } & -1628.5620 & 86.7379 & $179.6028^{* * *}$ \\
\hline & 1773.8090 & 97.7968 & 92.0459 \\
\hline \multirow[t]{2}{*}{ Risk } & 91.9238 & -105.1854 & 74.4162 \\
\hline & 1464.1900 & 80.7263 & 75.9793 \\
\hline \multirow[t]{2}{*}{ Size } & 89.7842 & -2.1517 & -6.9899 \\
\hline & 77.1960 & 4.2561 & 4.0058 \\
\hline \multirow[t]{2}{*}{ CSR } & -244.3887 & 23.8777 & 3.6215 \\
\hline & 184.0593 & 10.1479 & 9.5511 \\
\hline F-Statistic & 1.0058 & 2.4588 & 1.1208 \\
\hline $\mathbf{N}$ & 10 & 10 & 10 \\
\hline
\end{tabular}

Note: ${ }^{*}, * * * * *$ indicates significance at $0.01,0.05$ and 0.10 , respectively. 
Industrials Industry

Table A5. Correlation Matrix for the Dependent and Explanatory Variables

\begin{tabular}{|c|c|c|c|c|c|c|}
\hline Variable & EPS & ROA & ROE & SIZE & RISK & CSR \\
\hline EPS & 1 & & & & & \\
\hline ROA & -0.22628 & 1 & & & & \\
\hline ROE & 0.856996 & -0.01885 & 1 & & & \\
\hline SIZE & 0.832758 & -0.4051 & 0.577952 & 1 & & \\
\hline RISK & 0.057592 & 0.212974 & -0.16315 & -0.23428 & 1 & \\
\hline CSR & 0.583434 & -0.26054 & 0.511223 & 0.738481 & -0.43153 & 1 \\
\hline
\end{tabular}

Table A6. Regressions for CSR and CFP

\begin{tabular}{|c|c|c|c|}
\hline \multirow{2}{*}{ Variable } & Regression 1 & Regression 2 & Regression 3 \\
\hline & EPS & ROE & ROA \\
\hline \multirow[t]{2}{*}{ Constant } & -4827.7810 & -42.6659 & 43.9632 \\
\hline & 2500.2940 & 86.3037 & 50.5470 \\
\hline \multirow[t]{2}{*}{ Risk } & 1006.7690 & 1.8041 & 6.5510 \\
\hline & 1072.9520 & 37.0355 & 21.6913 \\
\hline \multirow[t]{2}{*}{ Size } & 230.2608 & 2.5149 & -1.5155 \\
\hline & 116.4330 & 4.0190 & 2.3539 \\
\hline \multirow[t]{2}{*}{ CSR } & 79.0387 & 3.3564 & 1.6271 \\
\hline & 364.9793 & 12.5981 & 7.3786 \\
\hline F-Statistic & 3.2503 & 0.5390 & 0.2375 \\
\hline $\mathrm{N}$ & 7 & 7 & 7 \\
\hline
\end{tabular}

Note: ${ }^{*},{ }^{*}, * *$ indicates significance at $0.01,0.05$ and 0.10 , respectively. 
